\title{
Current Knowledge on Growth Hormone and Insulin-Like Growth Factors and their Role in the Central Nervous System: Growth Hormone in Down Syndrome
}

\author{
Åsa Myrelid*
}

Department of Women's and Children's Health, University Children's Hospital, S-751 85 Uppsala, Sweden

\begin{abstract}
Down syndrome (DS) is a chromosomal disorder associated with short stature and psychomotor delay. Growth hormone $(\mathrm{GH})$ and insulin-like growth factor I (IGF-I) are of interest in DS as the pronounced growth retardation coincides in time when GH becomes essential for growth. Simultaneously mean intelligence quotient (IQ) decreases markedly.

There is no evidence of a general GH deficiency in children with DS, but suboptimal endogenous production of GH and selective deficiency of IGF-I have been demonstrated. GH and IGF-I are important brain growth promoting factors. IGF receptors are present in brain cells from foetuses with DS, but there is no information as to whether disturbances of intracerebral GH binding or IGF-I production may contribute to the brain dysfunction in DS.

GH therapy normalized growth velocity and improved fine motor performance in young children with DS, but the limited therapy was followed by a marked "catch-down" growth and lacked effect on final height. In adolescents with DS treatment with GH during early childhood show some positive late effects, where subjects previously treated had greater head circumference and improved performance regarding cognitive function and motor skills.

Few studies have addressed the effect of GH in Down syndrome. Nevertheless, GH has been designated beneficial effects on cognition, energy, mood and behaviour through extensive studies in several other conditions and it is not unlikely that GH may have similar effects in DS. It should be emphasised that even small changes in psychomotor attainment may be of substantial importance in a developmentally delayed population.
\end{abstract}

Keywords: Down syndrome (DS), growth hormone (GH), cognition, motor development, growth.

\section{INTRODUCTION}

Down syndrome (DS) is named after John Langdon Down, the British physician who described the characteristics of individuals with the syndrome in 1866 [1]. It is associated with mental retardation, short stature, congenital malformations, especially of the heart, and metabolic and endocrine dysfunction [2].

Down syndrome, diagnosed by chromosome analysis, is a common disorder [3], with an incidence of about 1/800 live births $[4,5]$. The life expectancy in DS is reduced compared to that in the general population, although it has improved markedly in the last decades. In the 1940s the median age at death was 12 years [6], in 1983 it was 25 years, and in recent years the life expectancy has risen to 60 years [7].

\section{PSYCHOMOTOR DEVELOPMENT IN DOWN SYN- DROME}

Mental retardation (intelligence quotient, IQ, $<70$ ) is characterised by impaired cognitive functioning and deficits

*Address correspondence to this author at the Department of Women's and Children's Health, University Children's Hospital, S-751 85 Uppsala, Sweden; Tel: +46186110000 ; Fax: +46186115853 ;

E-mail: asa.myrelid@kbh.uu.se of adaptive behaviour (communication, self-help skills, social skills etc.) with onset before the age of 18 years. Instruments for testing of IQ include components relating to mental functioning as well as to the individuals' functional skills in their environment.

Mental retardation is a cardinal sign in DS, but the degree shows large individual variation. The range in development of a specific skill is much greater in children with DS than in other children. IQs of between 35 and 65 are common in DS $[8,9]$. The mean IQ declines with increasing age [10], especially evident between the ages of 6 months and 3 years due to an increase in range and variability in respect to developmental milestones.

Mental retardation is associated with a reduction of strength and an earlier onset of weariness during physical activity [11]. Moreover, in assessment of motor performance, children with DS score lower than other children matched for sex and mental age [12].

Motor skill is commonly classified on the basis of the muscle groups and limbs involved; that is gross motor skills and fine motor skills are recognised as movements that involve large muscles and fine muscles, respectively [13-15]. Major milestones, such as sitting, standing and grasping, are generally delayed in children with DS [16]. The altered 
development of motor functions may be due to the muscular hypotonia, ligamental laxity, poor balance and postural control that are commonly seen in the DS population [17]. Furthermore, individuals with DS require more time to learn movements as the movement complexity increases [17].

\section{STATURAL GROWTH IN DOWN SYNDROME}

Short stature is another characteristic feature of Down syndrome [18], but there is a pronounced individual variation. Final height in individuals with DS is approximately $20 \mathrm{~cm}$ lower than expected with regard to parental heights [19]. The short stature in DS is to a great extent due to relatively short legs [20-22].

The growth retardation of children with DS commences prenatally [23]. After birth, the growth velocity is most reduced between 6 months and 3 years of age [18, 24]. Puberty in DS generally occurs somewhat early and is associated with an impaired growth spurt $[18,19]$. The mean peak height velocity is significantly lower in persons with DS than in controls [25].

In addition, children with DS are overrepresented with regard to congenital and acquired disorders that may affect growth, i.e. congenital heart defects [26], hypothyroidism [27-29] and coeliac disease [30].

The mechanism responsible for the short stature in DS is as yet unclear. Much interest has been paid to growth hormone $(\mathrm{GH})$ and insulin-like growth factor I (IGF-I), as the pronounced growth retardation in DS coincides with the time when GH become essential for growth. Suboptimal production of GH [31] and a selective deficiency of IGF-I $[24,32]$ have been demonstrated in children with DS, but there is no clear evidence of a general GH deficiency [33].

\section{GROWTH HORMONE AND INSULIN-LIKE GROWTH FACTOR I}

Growth hormone is produced in the anterior pituitary and has effects on several organs. Synthesis of GH is stimulated by growth hormone releasing hormone (GHRH) and inhibited by somatostatin, both of which are hypothalamic hormones. The secretion of $\mathrm{GH}$ is pulsatile and repeated measurements, providing a $\mathrm{GH}$ profile, can be used to evaluate the ability to produce GH. Insulin-like growth factor I is produced in several organs, but the major part of circulating IGF-I is produced in the liver.

Growth hormone influences skeletal growth, by stimulating synthesis of IGF-I, starting in the second half of the first year. Further, a marked increase in GH secretion, after stimulation of sex steroids, is normally seen during puberty. Thereafter, the spontaneous GH secretion, and consequently also the production of IGF-I, progressively decrease during the life-span.

The GH/IGF-I axis may play a role in the level of cognitive functioning in adult life [34], and clinical experience leaves little doubt that $\mathrm{GH}$ has effects on behavioural functions related to quality of life [35]. Growth hormone therapy in adult patients with growth hormone deficiency (GHD) results in improved psychological well- being, possibly as a result of interaction with the endogenous opioid system in limbic structures [36].

Both GH and IGF-I have metabolic effects. In adult patients with GHD there are alterations in body composition leading to overweight, increased visceral fat and decreased bone mineral density $[37,38]$.

Little is known about GH secretion in DS. The few available studies concern children with DS [33,39], who seem to have reasonable endogenous GH concentrations [33]. Our group has recently shown that young adults with DS have a normal capacity to produce and release GH spontaneously [22], but in the adult DS population a poor stimulated GH response has been reported [40].

Reduced GH secretion may be caused by alterations in neural control of the somatotrophs in the hypothalamus [41]. Hypocellularity has been observed in the hypothalamic areas involved in this control in DS subjects [40]. Decreased secretion of GH may also be caused by several non-pituitary disorders, such as hypothyroidism [42, 43], coeliac disease [44] and obesity [45, 46].

There is a negative association between $\mathrm{GH}$ secretion and body mass index (BMI), which may be explained by changes in neuroendocrine control of the somatotrophic axis as well as by metabolic alterations [47]. Overweight and obesity, as based on BMI $\left(>25 \mathrm{~kg} / \mathrm{m}^{2}\right.$ and $>30 \mathrm{~kg} / \mathrm{m}^{2}$, respectively, as defined by WHO [48]), is a common concern in the DS population [46, 49-54]. The cause of obesity in DS is unknown, but is probably multifactorial, with contributions of endocrine abnormalities, reduced exercise, hypotonia, a depressed metabolic rate and poor eating behaviour [53].

Adults with DS and adults with GHD have several features in common, i.e. overweight, decreased bone mineral density, lack of initiative, an increased risk of depression, and loss of physical capacity.

Results obtained by our research group have shown normal levels of IGF-I, although in the lower end of the reference interval, in subjects with DS [22]. Similar results have been reported previously [55], but it has been difficult to show a significant correlation between the concentrations of GH and IGF-I [56]. However, we found that the level of IGF-I correlated positively to the area under the curve for spontaneous secretion of GH [22].

There is some controversy regarding the impact of body composition on the GH and IGF-I levels in overweight subjects. As mentioned above GH secretion is negatively associated with BMI [57], and the GH response in obese subjects has been reported to be as impaired as that in hypopituitary patients with severe GHD [47]. The common occurrence of insulin resistance and hyperinsulinism in obesity may allow normal IGF-I synthesis and secretion despite altered somatotroph function. There are reports of increased as well as decreased concentrations of IGF-I in obese subjects [58, 59]. Landin-Wilhelmsen et al. [59] suggested that low levels of IGF-I may be related to increased adipose tissue and decreased lean body mass [59], whereas Ghigo et al. [47] proposed that the increased levels of IGF-I might be a result of an increased GH sensitivity in 
obesity. Nevertheless, despite increased BMIs, no correlation between IGF-I and BMI was seen in the DS subjects in the study from our laboratory [22] or in those of a previous study [32].

\section{GROWTH HORMONE AND THE BRAIN}

Growth hormone as well as IGFs are important brain growth promoting factors with local actions in the central nervous system (CNS) [35]. Improved maturation, differentiation and growth of the CNS have been observed as secondary effects of an increase in neurotrophic factors resulting from stimulation by GH/IGF-I [60].

It has been shown that $\mathrm{GH}$ reaches the cerebrospinal fluid, and specific binding sites of GH have been localised in numerous areas in the brain [35]. Hence, the reported association between intelligence and head growth during childhood [61] might be partly explained by GH. Beneficial effects on cognition, energy, mood and behaviour have frequently been described in studies of GH therapy in children with Prader-Willi syndrome (PWS) [62, 63]. Turner syndrome (TS) [64], and GHD [64, 65] as well as in children born small for gestational age (SGA) [66]. When treated with GH, children born SGA have shown improvement in IQ, and the score correlates well with head growth [66]. Furthermore, it has been suggested that GH therapy might prevent retardation of mental development in PWS [63].

\section{GROWTH HORMONE AND COGNITIVE FUNCTION}

Very few investigations on GH treatment in children with DS have been performed [33, 67, 68]. However, from studies of the GH effect in other conditions, it may be concluded that GH has positive cognitive effects in children with PWS $[62,63]$, TS [64] and GHD [64, 65], as well as in children born SGA [66].

Growth hormone directly affects the central nervous system [35]. Receptors for GH have been found in several regions of the brain $[35,69,70]$, of which the receptors in the hippocampal area are particularly interesting, as they may mediate the actions of GH on memory and cognition [35]. In addition, GH may exert a local growth promoting effect on the brain [61]. An association between intelligence and head growth during childhood has been reported [61], and the IQ score correlates positively with increasing head circumference during GH therapy in SGA children [66].

In view of the mental retardation associated with DS, the growth of the head is of great interest. The deviation of head growth in children with DS increases with age, with a total decrease of -1.5 standard deviation (SD) from birth to the age of four years ( -0.5 standard deviation score (SDS) [71] and -2.0 SDS [71], respectively) [51].

Microencephaly is considered to be the main cause of mental retardation in DS [72], but there is also a delay in central myelination which correlates well with the extent of developmental delay [73]. Impaired neurogenesis during critical phases of brain building has been demonstrated in infants with DS and results in severe hypocellularity. Chakrabarti et al. [74] demonstrated that the reduced neural proliferation further correlated with the delayed synapse formation in the cortex and hippocampus in DS. Further, the cerebral, cerebellar and hippocampal volumes are decreased in DS [75]. These defects are likely to have a continuous impact on brain function in DS [74].

Intelligence per se is often questioned, particularly in assessment of cognitive functions in mentally retarded populations. Being mentally retarded implies having limitations in cognitive areas including abstract thinking, but also lacking necessary adaptive skills to deal with everyday life and being dependent on others. Many individuals with DS are described as being socially quite alert, a strength that helps them to communicate and take part in social settings, but with no relation to their level of intelligence.

\section{GROWTH HORMONE AND MOTOR PERFOR- MANCE}

Growth hormone has an anabolic effect on skeletal muscle [76]. The muscle mass is reported to increase within the first year of GH therapy in individuals with GHD as well as in children born SGA and children with PWS [76-80]. Exogenous GH also improves muscular function [78], and improvements of strength and agility are reported to occur during GH therapy in children with PWS [80].

Motor development is a cerebellar process in which practice and experience result in acquisition of skills to execute specific movements. Neuronal proliferation and migration in the cerebellum are long-lasting processes. It is not until the end of the first year of life that the different layers of the cerebellum reach the structure and complexity similar to that of an adult cerebellum [81]. The size of the cerebellum is reduced in subjects with DS as a result of growth retardation and delayed maturation [75]. Further, there are reports on reduced proliferation of neural stem cells and delayed formation of synapses in DS [72, 74].

It has been postulated that the motor problems in DS may be related to the delayed cerebellar maturation and the relatively small cerebellum $[16,82,83]$. Thus, previous findings of improved fine motor skill [67] and an increased head circumference [68] could theoretically be an effect of improved cerebellar maturation and growth during $\mathrm{GH}$ treatment, as a high density of IGF-I receptors in the cerebellum has been reported [84]. The presence of GH receptors has been confirmed in the human putamen [35] and in the rat and rabbit cerebellum [85]. It has further been demonstrated that GH replacement in GHD patients, by increasing the circulating IGF-I, yields a faster working memory performance and recruitment of task-associated prefrontal regions [86].

\section{GROWTH HORMONE THERAPY}

A study on the effects of thyroxine treatment in young children with DS [87] has shown it possible to improve early development and growth. Thus, the rationale for early GH treatment in DS is the neuronal growth-promoting and protective effects of GH and IGF-I [35, 88, 89].

There are some reports on GH treatment in children with DS [33, 67-68]. It has been found that GH therapy normalises the growth velocity, but "catch-down" growth 
was noted when the treatment was discontinued [33, 67]. Furthermore, Torrado et al. [68] reported an increase in head circumference SDS during GH treatment in children with DS, but no information on psychomotor function was given in that report.

We performed a follow-up study of children with DS who had been treated with daily injections of GH for three years during early childhood in order to investigate late effects of early GH treatment on growth and psychomotor development [21]. Fifteen adolescents with DS, previously treated with GH, and 15 age matched controls with DS were followed up in this study. Auxiological data of an additional 15 subjects with DS examined in the out-patient clinic during the same time period were used in order to obtain a larger DS control group.

The original study resulted in normalised growth velocity during the GH treatment and some improvement of fine motor skill at the end of treatment, but no significant effect on head circumference [67]. In the follow-up there were no differences between the GH treated subjects and the group of controls regarding final height [51] and adult weight [51]. The adolescents previously treated with $\mathrm{GH}$ had a larger head circumference SDS [90] than the group of controls [21].

When using scaled scores, standardised on a population without intellectual impairment, no differences were found between the groups in neither assessed cognitive performance nor motor function [21]. However, the mean raw point scores of the previously GH treated adolescents were consistently higher than those of the controls in all subtests of both cognitive and motor proficiency assessments [21].

The available data on GH therapy in DS are unanimous, with the reported effects entirely beneficial [33, 67-68]. There is a marked response to exogenous GH treatment in DS [33, 67-68], despite the previous findings of reasonable GH concentrations in DS children [33] and observations of normal GH secretion in young adults with DS.(22] Against this background, it may be suggested that in DS the effect of endogenous $\mathrm{GH}$ is reduced and that the bioactivity of circulating endogenous $\mathrm{GH}$ in this syndrome may be questioned [32].

The diabetic and leukaemogenic potential of GH therapy has been discussed in the literature [91, 92]. In view of the intrinsic predisposition to diabetes and leukaemia in the DS population [93]. GH treatment might further increase the risk of these diseases, a possibility which should be taken into account when GH treatment in persons with DS is discussed. None of the adolescents with DS were being or had been treated for diabetes or leukaemia. Neither were any other adverse effects, early or late, of the GH treatment observed in these subjects.

\section{CONCLUDING REMARKS}

Available data on GH treatment in children with DS are conclusive regarding the positive effect on short term statural growth during treatment. Further, there are reports on beneficial effects on head growth and fine motor skills in previous studies of GH therapy in children with DS.

In a recent follow-up by our group early $\mathrm{GH}$ treatment in children with DS has been shown to have some late beneficial effects. Growth hormone lacked effect on final height, but the previously treated subjects had an increased adult head circumference and showed some improvement in cognition and motor development. Our findings are in line with earlier reports on GH therapy in other conditions, but the results should be interpreted with caution with regards to the small number of subjects studied. However, the combined observations of greater head circumference and consistently higher scores in cognitive and motor functions in the previously treated group suggest that the differences between the groups are due to prior treatment. In this context, it must be emphasised that even a small change in psychomotor attainment can be of substantial importance in a developmentally delayed population

The improved motor performance of the previously GHtreated adolescents reported by our group [21] may be related to a direct effect on skeletal muscle mass and function. However, in view of the differences in fine motor skills described in the original study [67], the improved motor proficiency might also be derived from a CNS effect.

Future studies should not only include the effect of longterm GH treatment on larger cohorts but also focus on possible effects on adaptive skills and quality of life. Assessment of adaptive functioning is a way of broadening the concept of intellectual ability, and such data would present interesting complementary information in the investigation of the cognitive effects of GH treatment.

\begin{tabular}{|c|c|}
\hline \multicolumn{2}{|c|}{ ABBREVIATIONS } \\
\hline BMI & $=$ Body mass index \\
\hline CNS & $=$ Central nervous system \\
\hline DS & $=$ Down syndrome \\
\hline GH & $=$ Growth hormone \\
\hline GHD & $=$ Growth hormone deficiency \\
\hline GHRH & $=$ Growth hormone releasing hormone \\
\hline IGF-I & $=$ Insulin-like growth factor-I \\
\hline IQ & $=$ Intelligence quotient \\
\hline PWS & $=$ Prader-Willi syndrome \\
\hline SD & $=$ Standard deviation \\
\hline SDS & $=$ Standard deviation score \\
\hline SGA & $=$ Small for gestational age \\
\hline TS & $=$ Turner syndrome \\
\hline WHO & $=$ World Health Organization \\
\hline
\end{tabular}

\section{CONFLICT OF INTEREST}

Authors confirm that this article content has no conflict of interest. 


\section{ACKNOWLEDGEMENTS}

This work was carried out with financial support provided by funds from the Sävstaholm Society and the Swedish Research Council and by an unconditional grant from Pharmacia/Pfizer.

\section{REFERENCES}

[1] Langdon Down J. Observations on an ethnic classification of idiots. London Hosp Rep 1866; (3): 259-62.

[2] Antonarakis SE, Lyle R, Dermitzakis ET, Reymond A, Deutsch S. Chromosome 21 and down syndrome: from genomics to pathophysiology. Nat Rev Genet 2004. 5(10): 725-38.

[3] Mikkelsen M. Down syndrome: cytogenetical epidemiology. Hereditas 1977; 86(1): 45-50.

[4] Parker SE, Mai CT, Canfield MA, et al. Updated national birth prevalence estimates for selected birth defects in the United States, 2004-2006. Birth Defects Res A Clin Mol Teratol 2010; 88: 100816.

[5] Lindsten J, Marsk L, Berglund K, et al. Incidence of Down's syndrome in Sweden during the years 1968-1977. Hum Genet Suppl 1981; 2: 195-210.

[6] Bittles AH, Bower C, Hussain R, Glasson EJ. The four ages of Down syndrome. Eur J Public Health 2007; 17(2): 221-5.

[7] Henderson A, Lynch SA, Wilkinson S, Hunter M. Adults with Down's syndrome: the prevalence of complications and health care in the community. Br J Gen Pract 2007; 57(534): 50-5.

[8] Chapman R. Language and cognitive development in children and adolescents with DS. In: Miller J, Leavitt L, Leddy M, Eds. Improving the communication of people with Down syndrome. Baltimore: Brookes 1999; pp. 41-60.

[9] Abbeduto L, Warren SF, Conners FA. Language development in Down syndrome: from the prelinguistic period to the acquisition of literacy. Ment Retard Dev Disabil Res Rev 2007; 13(3): 247-61.

10] Carr J. Stability and change in cognitive ability over the life span: a comparison of populations with and without Down's syndrome. J Intellect Disabil Res 2005; 49(Pt 12): 915-28.

[11] Groden G. Relationships between intelligence, simple, and complex motor proficiency. Am J Ment Defic 1969; 74(3): 373-5.

[12] Connolly BH, Michael BT. Performance of retarded children, with and without Down syndrome, on the Bruininks Oseretsky Test of Motor Proficiency. Phys Ther 1986; 66(3): 344-8.

[13] Deitz JC, Kartin D, Kopp K. Review of the Bruininks-Oseretsky Test of Motor Proficiency, Second Edition (BOT-2). Phys Occup Ther Pediatr 2007; 27(4): 87-102.

[14] Bruininks R. Bruininks-Oseretsky Test of Motor Proficiency: Examinor's manual. Circle Pines, MN: American Guidance Service 1978.

[15] Bruininks R, Bruininks B. Bruininks-Oseretsky Test of Motor Proficiency, $2^{\text {nd }}$ ed. Minneapolis, MA: NCS Pearson 2005.

[16] Spano M, Mercuri E, Rando T, et al. Motor and perceptual-motor competence in children with Down syndrome: variation in performance with age. Eur J Paediatr Neurol 1999; 3(1): 7-13.

[17] Palisano RJ, Walter SD, Russell DJ, et al. Gross motor function of children with down syndrome: creation of motor growth curves. Arch Phys Med Rehabil 2001; 82(4): 494-500.

[18] Cronk C, Crocker AC, Pueschel SM, et al. Growth charts for children with Down syndrome: 1 month to 18 years of age. Pediatrics 1988; 81(1): 102-10.

[19] Arnell H, Gustafsson J, Ivarsson SA, Annerén G. Growth and pubertal development in Down syndrome. Acta Paediatr 1996; 85(9): 1102-6.

[20] Barden HS. Growth and development of selected hard tissues in Down syndrome: a review. Hum Biol 1983; 55(3): 539-76.

[21] Myrelid Å, Bergman S, Elfvik SM, et al. Late effects of early growth hormone treatment in Down syndrome. Acta Paediatr 2010; 99(5): 763-9.

[22] Myrelid Å, Frisk P, Stridsberg M, Anneren G, Gustafsson J. Normal growth hormone secretion in overweight young adults with Down syndrome. Growth Horm IGF Res 2010; 20(2): 174-8.

[23] Kurjak A, Kirkinen P. Ultrasonic growth pattern of fetuses with chromosomal aberrations. Acta Obstet Gynecol Scand 1982; 61(3): 223-5.
[24] Sara VR, Gustavson KH, Annerén G, Hall K, Wetterberg L. Somatomedins in Down's syndrome. Biol Psychiatry 1983; 18(7): 803-11.

[25] Kimura J, Tachibana K, Imaizumi K, Kurosawa K, Kuroki Y Longitudinal growth and height velocity of Japanese children with Down's syndrome. Acta Paediatr 2003; 92(9): 1039-42.

[26] Cullum L, Liebman J. The association of congenital heart disease with Down's syndrome (mongolism). Am J Cardiol 1969; 24(3): 354-7.

[27] Gruneiro de PL, Chiesa A, Bastida MG, Alonso G, Finkielstain G, Heinrich JJ. Thyroid dysfunction and high thyroid stimulating hormone levels in children with Down's syndrome. J Pediatr Endocrinol Metab 2002; 15(9): 1543-8.

[28] Pueschel SM, Orson JM, Boylan JM, Pezzullo JC. Adolescent development in males with Down syndrome. Am J Dis Child 1985 1985; 139(3): 236-8.

[29] Pueschel SM, Jackson IM, Giesswein P, Dean MK, Pezzullo JC Thyroid function in Down syndrome. Res Dev Disabil 1991; 12(3): 287-96.

[30] George EK, Mearin ML, Bouquet J, et al. High frequency of celiac disease in Down syndrome. J Pediatr 1996; 128(4): 555-7.

[31] Castells S, Beaulieu I, Torrado C, Wisniewski KE, Zarny S, Gelato MC. Hypothalamic versus pituitary dysfunction in Down's syndrome as cause of growth retardation. J Intellect Disabil Res 1996; 40 ( Pt 6): 509-17.

[32] Ragusa L, Valetto MR, Proto C, et al. IGF-I levels in prepubertal and pubertal children with Down syndrome. Minerva Endocrinol 1998; 23(2): 31-6.

[33] Annerén G, Sara VR, Hall K, Tuvemo T. Growth and somatomedin responses to growth hormone in Down's syndrome. Arch Dis Child 1986; 61(1): 48-52.

[34] Stouthart PJ, Deijen JB, Roffel M, Delemarre-van de WA. Quality of life of growth hormone $(\mathrm{GH})$ deficient young adults during discontinuation and restart of GH therapy. Psychoneuroendocrinology 2003; 28(5): 612-26.

[35] Nyberg F. Growth hormone in the brain: characteristics of specific brain targets for the hormone and their functional significance. Front Neuroendocrinol 2000 2000; 21(4): 330-48.

[36] Spiegel K, Kourides IA, Pasternak GW. Different receptors mediate morphine-induced prolactin and growth hormone release. Life Sci 1982; 31(20-21): 2177-80.

[37] Mukherjee A, Murray RD, Shalet SM. Impact of growth hormone status on body composition and the skeleton. Horm Res 2004; 62 (Suppl 3): 35-41.

[38] Boot AM, van der Sluis IM, Krenning EP, de Muinck K-SSM. Bone Mineral Density and Body Composition in Adolescents with Childhood-Onset Growth Hormone Deficiency. Horm Res 2009; 71(6): 364-71.

[39] Castells S, Torrado C, Bastian W, Wisniewski KE. Growth hormone deficiency in Down's syndrome children. J Intellect Disabil Res 1992; 36 ( Pt 1): 29-43.

[40] Beccaria L, Marziani E, Manzoni P, et al. Further evidence of cholinergic impairment of the neuroendocrine control of the GH secretion in Down's syndrome. Dement Geriatr Cogn Disord. 1998; 9(2): 78-81.

[41] Arvat E, Gianotti L, Ragusa L, et al. The enhancing effect of pyridostigmine on the $\mathrm{GH}$ response to GHRH undergoes an accelerated age-related reduction in Down syndrome. Dementia 1996 ; 7(5): 288-92.

[42] Chernausek SD, Underwood LE, Utiger RD, Van Wyk JJ. Growth hormone secretion and plasma somatomedin-C in primary hypothyroidism. Clin Endocrinol (Oxf) 1983; 19(3): 337-44.

[43] Williams T, Maxon H, Thorner MO, Frohman LA. Blunted growth hormone $(\mathrm{GH})$ response to GH-releasing hormone in hypothyroidism resolves in the euthyroid state. J Clin Endocrinol Metab1985; 61(3): 454-6.

[44] Bozzola M, Giovenale D, Bozzola E, et al. Growth hormone deficiency and coeliac disease: an unusual association? Clin Endocrinol (Oxf) 2005; 62(3): 372-5.

[45] Nam SY, Marcus C. Growth hormone and adipocyte function in obesity. Horm Res 2000; 53 (Suppl 1): 87-97.

[46] Savastano S, Di Somma C, Belfiore A, et al. Growth hormone status in morbidly obese subjects and correlation with body composition. J Endocrinol Invest 2006; 29(6): 536-43. 
[47] Ghigo E, Aimaretti G, Corneli G. Diagnosis of adult GH deficiency. Growth Horm IGF Res 2008; 18(1): 1-16.

[48] Physical status: the use and interpretation of anthropometry. Report of a WHO Expert Committe. Geneva: World Health Organization 1995. Report No.: WHO Technical Report Series 854.

[49] Bhaumik S, Watson JM, Thorp CF, Tyrer F, McGrother CW. Body mass index in adults with intellectual disability: distribution, associations and service implications: a population-based prevalence study. J Intellect Disabil Res 2008; 52(Pt 4): 287-98.

[50] Melville CA, Cooper SA, McGrother CW, Thorp CF, Collacott R. Obesity in adults with Down syndrome: a case-control study. J Intellect Disabil Res 2005; 49(Pt 2): 125-33.

[51] Myrelid A, Gustafsson J, Ollars B, Annerén G. Growth charts for Down's syndrome from birth to 18 years of age. Arch Dis Child 2002; 87(2): 97-103.

[52] Rubin SS, Rimmer JH, Chicoine B, Braddock D, McGuire DE. Overweight prevalence in persons with Down syndrome. Ment Retard 1998; 36(3): 175-81

[53] Prasher VP. Overweight and obesity amongst Down's syndrome adults. J Intellect Disabil Res 1995; 39 ( Pt 5): 437-41.

[54] Bell AJ, Bhate MS. Prevalence of overweight and obesity in Down's syndrome and other mentally handicapped adults living in the community. J Intellect Disabil Res 1992; 36 ( Pt 4): 359-64.

[55] Hestnes A, Stovner LJ, Husøy O, Følling I, Sjaastad O. Somatomedin C (insulin-like growth factor 1) in adults with Down's syndrome. J Ment Defic Res 1991; 35 (Pt 3): 204-8.

[56] Svensson J, Johannsson G, Bengtsson BÅ. Insulin-like growth factor-I in growth hormone-deficient adults: relationship to population-based normal values, body composition and insulin tolerance test. Clin Endocrinol (Oxf) 1997; 46(5): 579-86.

[57] Veldhuis JD, Iranmanesh A. Physiological regulation of the human growth hormone $(\mathrm{GH})$-insulin-like growth factor type I (IGF-I) axis: predominant impact of age, obesity, gonadal function, and sleep. Sleep 1996; 19(10 Suppl): S221-4.

[58] Juul A, Bang P, Hertel NT, et al. Serum insulin-like growth factor-I in 1030 healthy children, adolescents, and adults: relation to age, sex, stage of puberty, testicular size, and body mass index. J Clin Endocrinol Metab 1994; 78(3): 744-52.

[59] Landin-Wilhelmsen K, Wilhelmsen L, Lappas G, et al. Serum insulin-like growth factor I in a random population sample of men and women: relation to age, sex, smoking habits, coffee consumption and physical activity, blood pressure and concentrations of plasma lipids, fibrinogen, parathyroid hormone and osteocalcin. Clin Endocrinol (Oxf) 1994; 41(3): 351-7.

[60] Hodge RD, D'Ercole AJ, O'Kusky JR. Insulin-like growth factor-I (IGF-I) inhibits neuronal apoptosis in the developing cerebral cortex in vivo. Int J Dev Neurosci 2007; 25(4): 233-41.

[61] Arends NJ, Boonstra VH, Hokken-Koelega AC. Head circumference and body proportions before and during growth hormone treatment in short children who were born small for gestational age. Pediatrics 2004; 114(3): 683-90.

[62] Lindgren AC, Hagenäs L, Müller J, et al. Growth hormone treatment of children with Prader-Willi syndrome affects linear growth and body composition favourably. Acta Paediatr 1998; 87(1): 28-31.

[63] Myers SE, Whitman BY, Carrel AL, Moerchen V, Bekx MT, Allen DB. Two years of growth hormone therapy in young children with Prader-Willi syndrome: physical and neurodevelopmental benefits. Am J Med Genet A 2007; 143(5): 443-8.

[64] Ross JL. Effects of growth hormone on cognitive function. Horm Res 2005; 64 (Suppl 3): 89-94.

[65] Smith MO, Shaywitz SE, Shaywitz BA, Gertner JM, Raskin LA, Gelwan EM. Exogenous growth hormone levels predict attentional performance: a preliminary report. J Dev Behav Pediatr 1985; 6(5): 273-8.

[66] Hokken-Koelega A, van Pareren Y, Arends N. Effects of growth hormone treatment on cognitive function and head circumference in children born small for gestational age. Horm Res 2005; 64 (Suppl 3): 95-9.

[67] Annerén G, Tuvemo T, Carlsson SC, et al. Growth hormone treatment in young children with Down's syndrome: effects on growth and psychomotor development. Arch Dis Child 1999; 80(4): 334-8.

[68] Torrado C, Bastian W, Wisniewski KE, Castells S. Treatment of children with Down syndrome and growth retardation with recombinant human growth hormone. J Pediatr 1994; 119(3): 47883.

[69] Lobie PE, Zhu T, Graichen R, Goh EL. Growth hormone, insulinlike growth factor I and the CNS: localization, function and mechanism of action. Growth Horm IGF Res 2000; 10 (Suppl B): S51-6.

[70] Nyberg F, Burman P. Growth hormone and its receptors in the central nervous system--location and functional significance. Horm Res 1996; 45(1-2): 18-22.

[71] Karlberg P, Taranger J, Engström I, et al. Physical growth from birth to 16 years and longitudinal outcome of the study during the same age period. Acta Paediatr Scand Suppl 1976; (258): 7-76.

[72] Guidi S, Bonasoni P, Ceccarelli C, et al. Neurogenesis impairment and increased cell death reduce total neuron number in the hippocampal region of fetuses with Down syndrome. Brain Pathol 2008; 18(2): 180-97.

[73] Koo BK, Blaser S, Harwood-Nash D, Becker LE, Murphy EG Magnetic resonance imaging evaluation of delayed myelination in Down syndrome: a case report and review of the literature. J Child Neurol 1992; 7(4): 417-21

[74] Chakrabarti L, Galdzicki Z, Haydar TF. Defects in embryonic neurogenesis and initial synapse formation in the forebrain of the Ts65Dn mouse model of Down syndrome. J Neurosci 2007; 27(43): 11483-95.

[75] Buxhoeveden D, Fobbs A, Roy E, Casanova M. Quantitative comparison of radial cell columns in children with Down's syndrome and controls. J Intellect Disabil Res 2002; 46(Pt 1): 7681.

[76] Klefter O, Feldt-Rasmussen U. Is increase in bone mineral content caused by increase in skeletal muscle mass/strength in adult patients with growth hormone $(\mathrm{GH})$ treated $\mathrm{GH}$ deficiency? A systematic literature analysis. Eur J Endocrinol 2009; 13: 13.

[77] Schweizer R, Martin DD, Haase M, et al. Similar effects of longterm exogenous growth hormone $(\mathrm{GH})$ on bone and muscle parameters: a pQCT study of GH-deficient and small-forgestational-age (SGA) children. Bone 2007; 41(5): 875-81.

[78] Schweizer R, Martin DD, Schonau E, Ranke MB. Muscle function improves during growth hormone therapy in short children born small for gestational age: results of a peripheral quantitative computed tomography study on body composition. J Clin Endocrinol Metab 2008; 93(8): 2978-83.

[79] Lissett CA, Shalet SM. Effects of growth hormone on bone and muscle. Growth Horm IGF Res 2000; 10 (Suppl B): S95-101.

[80] Carrel AL, Allen DB. Prader-Willi syndrome: how does growth hormone affect body composition and physical function? J Pediatr Endocrinol Metab 2001; 14 (Suppl 6): 1445-51.

[81] Dobbing J, Sands J. Quantitative growth and development of human brain. Arch Dis Child 1973; 48(10): 757-67.

[82] Connolly BH, Morgan SB, Russell FF, Fulliton WL. A longitudinal study of children with Down syndrome who experienced early intervention programming. Phys Ther 1993; 73(3): 170-9; discussion $9-81$

[83] Moldrich RX, Dauphinot L, Laffaire J, Rossier J, Potier MC. Down syndrome gene dosage imbalance on cerebellum development. Prog Neurobiol 2007; 82(2): 87-94.

[84] Adem A, Jossan SS, d'Argy R, et al. Insulin-like growth factor 1 (IGF-1) receptors in the human brain: quantitative autoradiographic localization. Brain Res 1989; 503(2): 299-303.

[85] Lincoln DT, el-Hifnawi E, Sinowatz F, Waters MJ. Immunohistochemical localization of growth hormone receptor binding protein in the mammalian cerebellum. Ann Anat 1994; 176(5): 419-27.

[86] Arwert LI, Veltman DJ, Deijen JB, van Dam PS, Drent ML. Effects of growth hormone substitution therapy on cognitive functioning in growth hormone deficient patients: a functional MRI study. Neuroendocrinology 2006; 83(1): 12-9.

[87] van Trotsenburg AS, Vulsma T, van Rozenburg-Marres SL,et al. The effect of thyroxine treatment started in the neonatal period on development and growth of two-year-old Down syndrome children: a randomized clinical trial. J Clin Endocrinol Metab 2005; 90(6) 3304-11

[88] Isgaard J, Åberg D, Nilsson M. Protective and regenerative effects of the GH/IGF-I axis on the brain. Minerva Endocrinol 2007; 32(2): 103-13.

[89] Frago LM, Paneda C, Dickson SL, Hewson AK, Argente J, Chowen JA. Growth hormone (GH) and GH-releasing peptide-6 
increase brain insulin-like growth factor-I expression and activate intracellular signaling pathways involved in neuroprotection. Endocrinology 2002; 143(10): 4113-22.

[90] Fredriks AM, van Buuren S, Burgmeijer RJ, et al. Continuing positive secular growth change in The Netherlands 1955-1997. Pediatr Res 2000; 47(3): 316-23.
[91] Jeffcoate W. Growth hormone therapy and its relationship to insulin resistance, glucose intolerance and diabetes mellitus: a review of recent evidence. Drug Saf 2002; 25(3): 199-212.

[92] Blethen SL. Leukemia in children treated with growth hormone. Trends Endocrinol Metab 1998; 9(9): 367-70.

[93] Kodish E, Cuttler L. Ethical issues in emerging new treatments such as growth hormone therapy for children with Down syndrome and Prader-Willi syndrome. Curr Opin Pediatr 1996; 8(4): 401-5.

(C) Åsa Myrelid; Licensee Bentham Open.

This is an open access article licensed under the terms of the Creative Commons Attribution Non-Commercial License (http://creativecommons.org/licenses/by$\mathrm{nc} / 3.0 /$ ) which permits unrestricted, non-commercial use, distribution and reproduction in any medium, provided the work is properly cited. 